\title{
Mapas textuales de la península de Yucatán en el Caribe Continental: narrativas de huracanes*
}

\begin{abstract}
Margaret Shrimpton Masson
Afiliada institucionalmente en el área de Literatura Latinoamericana en la Facultad de Ciencias Antropológicas, de la Universidad Autónoma de Yucatán (México). Correo electrónico mshrimp@correo.uady.mx. La autora es doctora en Ciencias Filológicas por la Universidad de La Habana (Cuba) y es miembro del Sistema Nacional de Investigadores (México). Es integrante del Cuerpo Académico Estudios Literarios de la Universidad Autónoma de Yucatán - UADY (México). ORCID ID: orcid.org/0000-0002-0518-4326. Recientemente ha publicado, entre otros: "La pagoda: migración, género e identidad en el Gran Caribe" (Prólogo) en Powell, Patricia La Pagoda, trad. Rosana Herrera Martín (Bogotá: Lasiren Editores, 2019) y en coautoría "Memoria e identidades en Celestún, Yucatán. Relatos de pesca, sal y ecoturismo" en Múltiples voces, diversos diálogos, (Eds). Leirana Alcocer, Silvia Cristina y Rosado Avilés, Celia (Mérida: Universidad Autónoma de Yucatán - UADY, 2017). Entre sus temas de interés se encuentran: Literatura, ideología y sociedad.
\end{abstract}

Recibido: 2 de diciembre de 2018

Aprobado: 7 de marzo de 2019

Modificado: 25 de marzo de 2019

Artículo de investigación científica

DOI: http://dx.doi.org/10.15648/hc.37.2020.7

* Este artículo forma parte del proyecto "Representaciones literarias de insularidad en escritores de Yucatán, Belice y Guyana. Hacia un modelo para el Caribe continental (Conacyt CB257673)" financiado por el Consejo Nacional de Ciencia y Tecnología - CONACYT Ciencia Básica 2015 (México). Esta publicación está bajo una licencia Creative Commons Reconocimiento-NoComercial 4.0 


\section{Mapas textuales de la península de Yucatán en el Caribe Continental: narrativas de huracanes}

\section{Resumen}

Empleando un corpus que incluye textos escritos y orales de la Yucatán, este artículo muestra cómo la memoria cultural nos habilita para crear una cartografía de la región del Caribe continental, por medio de la traza de rutas y signos de los huracanes, narrados en estos relatos. Escritos y/o narrados en español y en maya, y con su origen en los puertos costeros y también en los pueblos al interior, estas narrativas de huracanes revelan un intricado y complejo mapeo de la zona de huracanes en el Caribe continental. Hago hincapié en cómo el huracán, leída como metanarrativa (Schwartz ${ }^{1}$ ), no solamente teje las historias vividas por el impacto de la tormenta, y el mapa que resultaría, sino esta investigación prioriza una lectura que ofrece una "manera de mirar" (Lamming), una manera de sonar (Brathwaite) y una manera de contar (Berger), que juntos revelan el huracán como leitmotif para comprender la memoria cultural de la región.

Palabras clave: Caribe, Yucatán, ecocritica, maya, memoria cultural, cartografias.

\section{Mapping the Yucatan Peninsula from the Mainland Caribbean: Hurricane Stories}

\section{Abstract}

Using a corpus that includes both written and oral stories from the Yucatan this paper shows how cultural memory can enable us to create a cartography of our mainland Caribbean region by tracing the routes and signs of hurricanes in these narratives. Written and told in Spanish and in Maya, and originating in coastal towns and also in rural villages from the interior, these hurricane narratives reveal an intricate and complex mapping of the hurricane zone in the mainland Caribbean. I draw attention particularly to how the hurricane, read as a metanarrative $\left(S c h w a r t z^{2}\right)$, not only enables us to weave together the lived experiences of the impact of the storms as a literature of disasters and to draw a spatial map of the "hurricane zone"; but also discusses how these stories offer "a way of seeing", "a way of speaking" and "a way of telling" that reveal the hurricane as a leitmotif for understanding the cultural memory of the region.

Key Words: Caribbean, Yucatan, ecocriticism, maya, cultural memory, cartographies.

1 Stuart B Schwartz, Sea of Storms. A History of Hurricanes in the Greater Caribbean from Columbus to Katrina (Princeton: Princeton University Press, 2015), xi.

2 Schwartz, Sea of Storms, xi 
Mapas textuais da península de Yucatán no Caribe Continental: narrativas de furacões

\section{Resumo}

Usando um corpus que inclui textos escritos e orais de Yucatán, este artigo mostra como a memoria cultural permite que criemos uma cartografia da região Caribe, de acordo a um desenho de roteiros e signos de furacões narrados nos textos orais e escritos, sejam em espanhol ou maia e com sua origem nos portos das costas e também nos povos do interior. Estas narrativas de furacões revelam um mapeio intricado e complexo da área de furacões no Caribe continental. Se focaliza como o furacão, como uma metanarrativa para ler o Caribe $\left(S_{c h w a r t z}{ }^{3}\right.$ ), não só tece as histórias vividas pelo impacto da tormenta, senão que fornece um mapa, mas esta pesquisa prioriza uma leitura que oferece uma "maneira de olhar" (Lamming), uma maneira de soar (Brathwaite) e uma maneira de contar (Berger) que em conjunto revelam que o furacão é um leitmotif para compreender a memoria cultural da região.

Palavras-chave: Caribe, Yucatán, ecocrítica, maia, memoria cultural, cartografias.

\section{Cartes textuelles de la péninsule du Yucatan dans la caraïbe continentale: récits d'ouragans}

\section{Résumé}

Avec un corpus riche de textes écrits et oraux, cet article montre comment la mémoire culturelle nous permet de créer une cartographie de la péninsule du Yucatan, à travers le tracé des itinéraires des ouragans tels qu'ils sont mis en récits. Racontés en espagnol et en maya, prenant leur origine dans les ports frontaliers et les villages de l'intérieur de la péninsule, ces récits d'ouragans mettent au jour une cartographie complexe des ouragans dans la Caraibe continentale. J'aborde ces textes comme métanarratifs, Sea of Storms (Schwartz $\left.{ }^{4}\right)$ et j'analyse non seulement comment l'ouragan tisse des récits de vies et raconte ses conséquences après la tempête; mais encore, je propose une lecture qui offre une nouvelle manière de voir (Lamming), de résonner (Brathwaite) et de raconter (Berger); à elles trois, elles permettent de saisir l'ouragan comme un leitmotiv particulièrement efficace pour comprendre la mémoire culturelle de la région.

Mots clés: Caraibe, Yucatán, ecocritique, maya, mémoire culturelle, cartographies.

3 Schwartz, Sea of Storms, xiNo hay número de páginas?-

4 Schwartz, Sea of Storms. xi 


\section{INTRODUCCIÓN}

\section{The landscape is alive, it's a living text Wilson Harris}

En situaciones de desastre, los seres humanos buscamos narrar nuestras historias: una narrativa que registra, cuenta y fija hechos, pero que también descarga emociones, resguarda memorias (lo perdido y lo salvado), crea vínculos con el pasado, y genera historias para el futuro. Desde el interior de los escenarios de desastres naturales, el tiempo se registra a partir de la experiencia vivida y no de manera lineal. Una de las frases más repetidas en el lenguaje coloquial de las poblaciones impactadas es la que fija "lo que estuvimos haciendo" cuando entró el huracán o cuando tembló la tierra. Aquel fragmento de tiempo cuando todo se revela con claridad y el momento queda dibujado por siempre en la memoria. Mientras escribo estas líneas, México vive el post-sismo del 19 de septiembre 2017, repitiendo en el mismo día, el terremoto de 1985; y en el Caribe se atraviesan los días "post-huracán(es)" de una de las peores temporadas ciclónicas en la historia reciente. Los huracanes Harvey, Irma y María, dejaron su huella profunda en la cuenca Caribe durante 2017, uniéndose a los recuerdos de Gilberto, Isidoro, Mitch, Wilma y Katrina, entre otros. Todos, tenemos un huracán en la memoria.

Uno de mis intereses al recuperar las voces y los textos en torno a los huracanes en la Península de Yucatán es lograr mapear las rutas, límites y conexiones de esta zona del Caribe continental, y construir una mirada sobre este territorio desde la memoria cultural, o de la historia profun$\mathrm{da}^{5}$, registrada en distintos relatos en torno al impacto y la experiencia vivida de los huracanes. Lejos de ser fenómenos naturales vinculados solamente a la costa, o que permiten definir las culturas costeñas particularmente, los huracanes de la región impactan las tierras al interior

5 Stuart B Schwartz, Conferencia "In the Shadow of Flora and Katrina: Response to Hurricanes Irma and Maria in the Neoliberal Age" pronunciada en Instituto de Estudios del Caribe, (IEC), Universidad de Puerto Rico, Río Piedras (UPR), 9 de febrero 2018 http://www.uprrp.edu/ 
de la península con frecuencia, como se observa en el mapa proporcionado por Gertrudis Guzmán Noh y Juan Manuel Rodríguez Estevés ${ }^{6}$. El mapa traza las rutas y las travesías, y como resultado, demuestra que toda la península guarda una memoria de huracanes que cuenta una experiencia compartida, aunque diferenciada.

\section{Mapa No. 1}

Estado de Yucatán

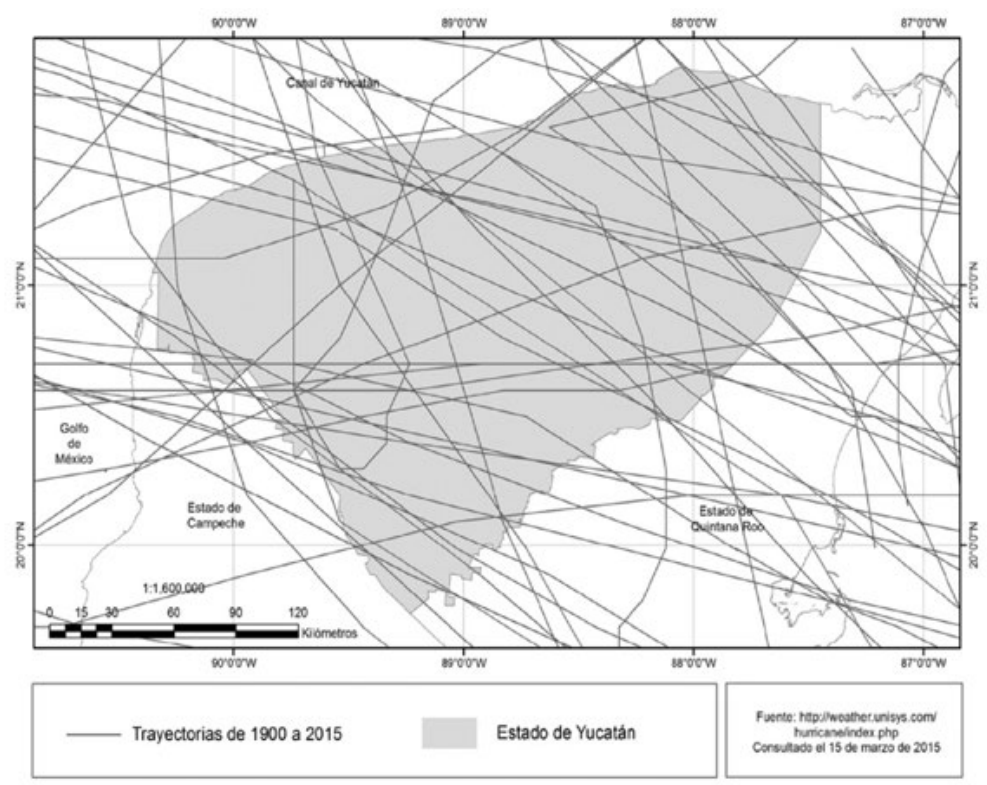

Fuente: http://weather.unisys.com/hurricane/index.php Consultado el 15 de marzo de 2015.

Mapa proporcionado por Gertrudis Guzmán Noh y Juan Manuel Rodríguez Estevés.

Este artículo registra los recursos narrativos empleados en el proceso de narrar (desde diversos géneros) los huracanes y sus impactos, ofreciendo una lectura del Caribe continental desde las costas y las zonas interiores de la península de Yucatán. El huracán se vislumbra como

6 El mapa de Guzmán y Rodríguez muestra la trayectoria de los múltiples huracanes que han cruzado la península desde 1900, citando a Herman W. Konrad ("Caribbean tropical storms. Ecological implications for pre-Hispanic and contemporary Maya subsistence practices on the Yucatan Peninsula", Revista Mexicana del Caribe, año 1, N 1 (1996): 99-130), quien demostró la dirección de las trayectorias de los ciclones de oriente a occidente, del Atlántico al Golfo. (Gertrudis Guzmán y Juan Manuel Rodríguez, "Elementos de la vulnerabilidad ante huracanes", Política y Cultura, $\mathrm{N}^{\circ} 45$, (2016): 187. 
tropo que plasma en imágenes y relatos las experiencias vividas entre diversas comunidades y permite trazar rutas entre áreas costeñas y pueblos al interior, ofreciendo nuevos mecanismos para comprender a la región, desde el entorno natural. La discusión de las representaciones del huracán en diversos textos (testimonios, canciones, cuentos) escritos en español y en maya, evidencia un mapeo de la península como una "zona del huracán"7 y matiza las dinámicas y la conectividad entre costa e interior. El abordaje de estos materiales es orientado desde el marco de la ecocrítica en una postura que busca proporcionar nuevas maneras de leer los espacios y su articulación constante e inextricable con la experiencia humana ${ }^{8}$.

En el corpus encontramos elementos iterativos como el ruido y/o el silencio, el color, el agua (no el viento), el antropomorfismo y la ritualización de los huracanes. Son caracterizados como seres, y personificados de tal manera que cumplan un rol performativo en la comunidad como agentes de transmisión de relatos y memorias. Los grabados taínos (descritos por Fernando Ortiz) son indicativos de la capacidad multi-representacional de los huracanes, íconos de un dios-ser, con alas como aspas de viento. Corporaliza y personifica los vientos. La historia de la palabra huracán revela palimpsestos de las lenguas arahuacas, maya, español e inglés y, como Deckard explica, incorpora también su propio lenguaje ecológico9 .

7 El poeta beliceño, Yasser Musa se refiere a The Hurricane Zone en su poema de 2014, "Like a Dance", en Yasser Musa, The Girl in Black, (Belize City: Image Factory, 2014) http://www.yassermusa. com/uploads/3/4/7/0/3470758/the_girl_in_black_2014.pdf

8 Por una revisión amplia de las propuestas de la ecocrítica, así como los debates en torno a la tensión teórica que confronta "naturaleza" y "cultura", ver Serpil Oppermann, "Ecocriticism's Theoretical Discontents", Mosaic: A Journal for the Interdisciplinary Study of Literature Vol. 44, N², June (2011). Oppermann hace hincapié en la necesidad de desarrollar una perspectiva crítica en donde quepa tanto lo discursivo como lo material: "That is why we need to advance a critical perspective in which both discursivity and materiality (in other words, discursive practices and material phenomena) can be integrated in a relational approach" 2011: 155).

9 "The word hurricane itself was received into English from the Spanish huracán, which was lifted in turn from Arawak and Mayan languages: the Taino word hurican (devil wind), the Mayan storm god Hunraken. The word is thus a palimpsest of the long eruptive history of multiple colonizations, dispossessions and exterminations in the Caribbean, preserving the trace of Amerindian cultures and socio-ecological relations, and recording the intensity of experience of extreme weather condi- 
El material que abordo aquí se organiza a partir de tres ejes. El primero, desarrolla la metodología de trabajo que parte del huracán como una metanarrativa (Schwartz) que revela la historia profunda de la región. En el segundo eje, considero las propuestas teóricas de George Lamming (una manera de ver), de Kamau Brathwaite (de sonar) y de John Berger (de relatar). En Pleasures of Exile, publicado por primera vez en 1961, George Lamming escribe un capítulo fundamental e influyente para el pensamiento caribeño, "A way of seeing", en el cual aporta una lectura propia (caribeña) sobre el área, una manera de ver "local" que se opone a la mirada colonial; Brathwaite, en la muy citada conferencia de 1976 "A History of the Voice" hace explícita la innegable relación entre lenguaje y poder, y reclama una voz propia, -una manera de hablar o de sonar propios- que desestabiliza el discurso colonial metropolitano. Desde una disciplina y un lugar diferentes, el fotógrafo John Berger utiliza la imagen visual como un texto que reconstruye el significado desde los vacíos y los espacios ambiguos: "In the relationship between a photograph and words, the photograph begs for an interpretation, and the words usually supply it [...] Yet it might be that the photographic ambiguity, [...] could offer to photography a unique means of expression. Could this ambiguity suggest another way of telling?"10 La articulación de estas tres propuestas demuestra los diversos vínculos que se tejen entre pobladores, relatos y espacios caribeños. El tercer eje examina el corpus de relatos de la Península de Yucatán y muestra los resultados de una lectura del huracán como mapa textual, para entender las dinámicas, rutas y conectividades que construyen las identidades en el Caribe continental.

tions as it marked multiple cultures throughout a long temporality." Sharae Deckard, "The Political Ecology of Storms in Caribbean Literature", en The Caribbean: Aesthetics, World-Ecology, Politics, eds. Chris Campbell y Michael Niblett (Liverpool: University of Liverpool Press, 2016), 4-5.

10 George Lamming, Pleasures of Exile (London/New York: Allison and Busby, 1984); Kamau Brathwaite, A History of the Voice, Conferencia impartida en The University of The West Indies, Mona, Jamaica, 1976, posteriormente publicada en español en Roots (La Habana, Casa de las Americas, 1986); John Berger y Jean Mohr, Another Way of Telling (New York: First Vintage International 1995), 92. 


\section{LOS CUENTOS QUE NARRAN LOS CICLONES: UNA METODOLOGÍA PARA RECUPERAR LA MEMORIA}

\section{For me landscape has always been akin to mindscape \\ Kristine Simelda (2015)}

Cuando Kamau Brathwaite afirmó en 1986 que "The hurricane does not roar in pentameters"11, colocó el lenguaje mismo, al centro de un debate anticolonial y profundamente arraigado en conceptos identitarios. El pentámetro remitía a Shakespeare, La Tempestad, el lenguaje del colonialismo y el proceso de "definir para dominar" dos plenamente en cada isla caribeña a través de la lengua, la educación y la imposición de un canon literario que repetía los ritmos y plasmaba el control de la metrópoli. El huracán (no una simple tormenta) rugía con un lenguaje propio, y resonaba dentro de cada comunidad, volviéndose metáfora de un pensamiento decolonial. El eje central de este artículo es ese huracán: el huracán como factor natural, ecológico, cultural y también discursivo; generador de memorias, gestor de identida$\operatorname{des}^{13}$. Los huracanes son comprendidos como naturales (no supernaturales, mágicos o maravillosos), es decir, propios a la zona, no extraños. Schwartz afirma que desde el siglo XVI hasta la fecha, habrán azotado el Caribe unos 4000 o 5000 huracanes, y si bien siempre son "awesome

11 Kamau Brathwaite, "History of the Voice", en Roots (La Habana: Casa de las Americas, 1986). En una reciente publicación, Sharae Deckard afirma: "Brathwaite thus presents the "rhythm" of "environmental experience" as integral to the formation of Caribbean poetics [...]". Sharae Deckard, "The Political Ecology of Storms in Caribbean Literature", en The Caribbean: Aesthetics, World-Ecology, Politics, eds. Chris Campbell y Michael Niblett (Liverpool: University of Liverpool Press, 2016), 28.

12 Partiendo de la propuesta esbozada por Roberto González Echeverría (Myth and Archive: $A$ Theory of Latin American Narrative, Durham: Duke University Press, 1998), Pérez Aguilar dice: "El instrumento más poderoso que tuvo el europeo sobre sus sometidos fue la escritura. La historia de las Indias Occidentales anterior al encuentro fue exterminada a través de esta arma, pues las ambiciones de la expansión colonial se resumían en la premisa de eliminar para "escribir", y no precisamente reescribir, porque reescribir era reconocer una historia previa, la historia que para el europeo no debía existir. El ser portador de la escritura llevó al europeo a su más grande conquista: definir para dominar" (Adyani Pérez Aguilar, "Construyendo espacios, textos y paratextos: Wide Sargasso Sea (1966)" (Tesis de Licenciatura en Literatura Latinoamericana, Universidad Autónoma de Yucatán, 2014), 20.

13 Stuart B. Schwartz propone el estudio de las tormentas y las respectivas respuestas de las sociedades e instituciones en las zonas de impacto como una metanarrativa, que da cuenta de los procesos históricos y transculturales de la región. Schwartz, Sea of Storms, xi. 
and frightening", son también fenómenos cotidianos, esperados cada temporada: "Their regularity, seasonality and seemingly random appearance in various places within the region made moral interpretations of the storms difficult. [...] They were simply too frequent and too random $[\ldots]^{\prime 14}$. Ofrezco, entonces, una visión alternativa al discurso del huracán como desastre, al enfocar en el huracán como elemento que es a la vez constructivo. Mi intención es evidenciar cómo las literaturas de la región escriben su historia y la experiencia comunitaria por medio de sus huracanes, o bien, con el medio ambiente, natural, para trazar identidades entrelazados en la misma Península y entre la Península y el resto del Caribe. Sin subestimar el profundo impacto de los huracanes como fuerzas destructivas en las comunidades, estos relatos revelan una información distinta, otra narrativa del fenómeno.

Este ensayo analiza un corpus de textos originarios de la península de Yucatán, que registra los diversos elementos que conforman un repertorio del huracán, un archivo dinámico de poemas, canciones, recuerdos y anécdotas que se repiten a través de la zona del huracán ${ }^{15}$. Es decir, el artículo evidencia al huracán como texto, o como un mapa natural de la zona, que realiza una cartografía no solamente del mundo representado, sino la experiencia del mundo vivido. En este sentido, el huracán y sus relatos son elementos constitutivos del diálogo cultural en la sociedad ${ }^{16}$. La recurrencia del huracán en trabajos creativos y críticos en todo el Caribe me permite realizar un breve rastreo de textos de diversas áreas para identificar aquellos tropos recurrentes e iterativos, que aportan un marco de interpretación comparada para la lectura del corpus peninsular. ${ }^{17}$ De esta manera, el huracán se vuelve una estrategia

14 Schwartz, Sea of Storms, 31.

15 Por una revisión amplia de las propuestas de la ecocrítica, así como los debates en torno a la tensión teórica que confronta "naturaleza" y "cultura", ver Serpil Oppermann, "Ecocriticism's Theoretical Discontents", Mosaic: A Journal for the Interdisciplinary Study of Literature Vol. 44, № 2, June (2011). Oppermann hace hincapié en la necesidad de desarrollar una perspectiva crítica en donde quepa tanto lo discursivo como lo material (2011): 155.

16 Las ideas sobre ecocrítica y en particular las filosofías interdisciplinarias al centro de esta discusión han sido enriquecidas por conversaciones con el Dr. Charles M Pigott (University of Cambridge, UK) y en particular a raíz de la conferencia "Visiones ecológicas en la literatura maya", impartida en el Seminario Permanente "Estudios sobre el Caribe: perspectivas transdisciplinarias" Universidad Autónoma de Yucatán, 16 de marzo 2018).

17 Me refiero en esta sección específicamente a algunos de los trabajos de poesía y ficción que abordan 
narrativa que permite trazar la conectividad del área Caribe, repitiendo un patrón de raíz (pueblo y arraigo) y rizoma (experiencias compartidas a través del área), en la construcción de la memoria. Esta lectura permite un abordaje de los textos, así como también del huracán mismo, entendido como figura de una cosmovisión y generador de prácticas y experiencias reales ${ }^{18}$. En las obras de Olive Senior, Merle Collins, Kristine Simelda, Diana Muir y Lelawattee Manoo-Rahming ${ }^{19}$, el huracán configura un mapeo de experiencias cotidianas vividas con los huracanes. A veces figura oscura que inmersa la comunidad en situaciones de vulnerabilidad, el huracán es a la vez, generador de una narrativa de memoria que atraviesa rutas y huellas por la zona. Al escoger aquí un corpus escrito por mujeres, evito conscientemente referenciar aquel canon masculino (que aparece en guiños intertextuales en estas obras) para visibilizar otro corpus y otra caribeñidad alterna ${ }^{20}$.

El estudio de Jennifer Rahim sobre la obra de Olive Senior y Lorna Goodison, hace hincapié en las narrativas de huracanes de Senior en su poemario Gardening in the Tropics: "Her series of hurricane narratives

los huracanes de la zona. Para una revisión de la bibliografía ecocrítica, ver, Shrimpton "Cartografías de la memoria cultural caribeña. Eco-relatos en la "zona del huracán”, en Narrar el Caribe: visiones históricas de la región, ed. Laura Muñoz Mata, (Ciudad de México: Instituto Mora, en prensa, 2019).

18 Stephanie Posthumus en su estudio de la literatura francesa desde la ecocrítica, pregunta: "How then can reading be ecological? [...] without reducing a texts meaning to its socio-historical context, ecological readings acknowledge the link between creativity, imagination and the effects of particular world views and experiences of the world". Stephanie Posthumus, French 'Ecocritique': Reading Contemporary French Theory and Fiction Ecologicall (Toronto: University of Toronto Press, 2017), 6. Es en este sentido que empleo la lectura ecocritica.

19 Olive Senior es escritora nacida en Jamaica (1941) y radicada en Toronto, Canadá desde 1993. Gardening in the Tropics se publicó en 1994. Merle Collins es escritora nacida en Aruba en 1950, de Grenada. Tuvo una participación central en la Revolución de Grenada y dejó la isla en 1983. Kristine Simelda, escritora nacida en Estados Unidos, vive en la isla Dominica (Antillas menores) desde 1994. Se refiere a sí misma como escritora "transplantada viviendo en el trópico" (https://kristinesimelda. wordpress.com/about/). Diana Muir es una escritora e historiadora medioambientalista, de Nueva Inglaterra, EEUU. Lelawattee Manoo-Rahming es ingeniera de profesión y poeta y escritora. Nacida en Trinidad y Tobago, en 1960, de ascendencia hindú, vive en Nasau, Bahamas.

20 Ver: Sharae Deckard quien, en un importante estudio sobre la lectura del huracán en la literatura del Caribe, aborda Carpentier, Walcott, Brathwaite, García Márquez, Maximin, Césaire entre otros, al introducir la geo- poética del huracán. No obstante, recurre también a los textos de Grace Nichols, Zee Edgell y otras escritoras, cuando discute la construcción de identidad desde esta mirada del huracán. Sharae Deckard, "The Political Ecology of Storms in Caribbean Literature" en The Caribbean: Aesthetics, World-Ecology, Politics, eds. Chris Campbell y Michael Niblett, (Liverpool: University of Liverpool Press, 2016) 
tell of love, family, labour, survival, loss and aspirations. Ingenious metaphoric use is made of the major hurricanes that extensively damaged the Jamaican landscape and economy in 1903, 1944, 1951 (Charlie), and 1988 (Gilbert)"21. Aunque evidencia los aspectos destructivos como la muerte, la rabia y la vulnerabilidad de la población, Rahim introduce aquí un mapeo de la experiencia vivida en comunidades jamaiquinas, durante el siglo XX. El último, Gilberto, conocido en la zona como el "huracán del siglo" (XX), será narrado también por nuestros escritores yucatecos del Caribe continental, creando una serie de historias traslapadas, o palimpsestos que atraviesan la zona, conectando también continente e islas.

En Tout Moun ka Pléwé (Everybody Bawling) Merle Collins ofrece una aproximación al huracán como un ser poderoso y fantástico, capaz de mover árboles y de transformar paisajes. Marca temporalmente un antes y después en la historia personal y colectiva. El trato al huracán -en este caso, Janet ${ }^{22}$, es íntimo. Es un ser, casi como un vecino alojado no en la comunidad, sino en la memoria de ella:

"Today, when I tell my mother that the coconut tree had moved on the morning after Janet, and ask her if she remembers that, she laughs a little half don't-quite-believe-but can't-be-sure laugh and says, Well it couldn't move, and then she adds, Perhaps, and then she shrugs and says, Meself, I don't know. And then she comments, But plenty things happen with that Janet there, wi, leaving me to conclude that so much happened that the coconut tree moving from the back of the house

21 Jennifer Rahim, "From Archaeology to Iconology: Representations of the Tropics in Senior's 'Gardening in the Tropics' and in Goodison's 'To Us, all Flowers are Roses'”, Journal of West Indian Literature Vol. 8, Nº 2 (1999): 71.

22 Janet fue huracán de categoría 5, en septiembre de 1955. Impactó en Chetumal, Yucatán y luego de pasar por el Golfo de México volvió a impactar en Veracruz. El meteoro causó la muerte a más de 1000 personas y fue el primer huracán cuyo nombre fuese retirado de las listas. Su paso por las Antillas menores antes de impactar en tierras continentales, causó la muerte de 122 personas en las Grenadines, al pasar entre Grenada y Cariacou. Si bien la mayoría de los reportajes sobre Janet son de Yucatán y Belice, narrando una memoria del impacto, el cuento de Collins da cuenta de la memoria de su trayectoria, el fenómeno en movimiento. 
and settling itself, fully planted, in the front yard, was not as impossible after Janet as it would have been before"23.

Collins nos presenta el huracán de cerca. Es la visión desde adentro de la zona, y una perspectiva de intimidad, que guarda relación con los relatos de la península yucateca.

El poema "Stormy Weather", de Kristine Simelda se inscribe en la memoria con una voz lírica que canta a la naturaleza en la isla de Dominica y a los dioses guardianes, a la vez que escribe como trazo y huella en la tierra. Mama Glo, madre guardiana de las aguas, canta una balada a los mares, pero termina con una advertencia, pues su ofrenda no podrá detener la inevitable llegada del huracán. La voz de Mama Glo utiliza el ciclón como metáfora para advertir contra la pérdida de identidad. El huracán se convierte en mensajero, desdoblándose como fenómeno representativo de lo propio, de la ecología particular de la isla, portador de sus memorias, a la vez que portentoso augurio de destrucción. El huracán es codificado en referencias bio-ecológicas, una memoria natural que comprende el pasado y el presente y advierte sobre los peligros latentes de un futuro material. Este huracán sí es peligroso, pero es también comprendido desde un espacio propio: los mangos que son arrojados sobre los techos, el ruido de la lluvia, las piedras en la playa, las huellas de los pies en la arena ${ }^{24}$.

Historiadora y medioambientalista Diana Muir, cuenta "My Mother's Hurricanes", abordando los huracanes en Nueva Inglaterra (EEUU) como parte de un proceso ecológico que interactúa directamente con la sociedad. La narración autobiográfica modifica el enfoque alejándolo de un simple recuento de desastres para visualizar y codificar el huracán como un fenómeno natural recurrente y repetitivo; si bien no es predecible, sí se trazan patrones identificables y "historiables": "If the 1938 hurricane had hit earlier in September, when people were still at their beach houses, it would have killed thousands. If Hurricane Gloria had

23 Merle Collins, "Tout Moun ka Pléwé” (Everybody Bawling), Small Axe Vol. 11 (1) (2007): 1-2

24 Kristine Simelda, "Stormy Weather", WomanSpeak, A Journal of Writing and Art by Caribbean Women Vol. 8 (2016): versos 36-39 
hit six hours later, at high tide instead of low, the storm surge would have swept a wide swath of cottage-cluttered Rhode Island beach as free of buildings as it was when the Narragansett Indians fished and clammed there". ${ }^{25}$ Y continua, marcando el espacio como una cartografía trazada por los huracanes en los bosques: "Sixty years later it is still sometimes possible for a hiker to identify a swath of forest felled by the Great Hurricane"26.

Los poemas de Lelawattee Manoo-Rahming (Trinidad-Bahamas) no son simplemente poemas incidentales que mencionan huracanes, sino estos ocupan una sección específica y forman una serie discursiva dentro de su obra. En Immortelle and Bhandaaraa Poems Manoo-Rahming presenta una serie de poemas que explora la precariedad del ser humano, su mortalidad y los ciclos de vida. Es una colección íntima, enmarcada dentro de un pensamiento espiritual que se remite a los orígenes hindú-trinitarias de la poeta así como de lo pan-caribeño. Las cinco secciones son nombradas por las diosas hindúes Bhavani y Durga, la diosa taino Coatrischie, la diosa griega Hecate, y de nuevo, la diosa hindú Shakti. ${ }^{27}$ Es la sección dedicada a Coastrischie que incluye los poemas del huracán. La tercera de cinco secciones, no es casual que el huracán aparece como fuerza natural de vida y de muerte bajo la vigilancia de la diosa taíno de las aguas, de las lluvias. Si bien el Centro de Huracanes (NOAA http://www.noaa.gov/) mide la fuerza destructiva de los huracanes por los vientos, el temor de las comunidades es por el agua que se acumula por las lluvias y el crecimiento de mares y de ríos $^{28}$. La referencia más común en los relatos de los huracanes es en torno al agua, a las lluvias torrenciales y a las entradas del mar. Tanto en

25 Diana Muir, "My Mother's Hurricane, and Further Cautions", The North American Review Vol. 283, Nº 2 (1998): 5)

26 Muir, "My Mother's Hurricane", 7.

27 Sandra Pouchet Paquet, "Introduction", en Immortelle and Bhandaaraa Poems, Lelawattee Manoo-Rahming (Hong Kong: Proverse Hong Kong, 2011), 15.

28 Las recientes declaraciones del investigador Omar García Concepción (Instituto de Astronomía y Meteorología de la Universidad de Guadalajara), confirman este hecho. "El mayor riesgo (de un huracán) no es el viento en la costa, la marea que produce la tormenta y el oleaje; la causa de mayor destrucción es la lluvia y esta no tiene relación con la intensidad del ciclón" (Diario de Yucatán, Mérida, 7 de marzo, 2018) 
el poema de Simelda, como los de Manoo-Rahming, se encomienda la comunidad a las diosas del agua.

"Coatrischie: Tempest-Raising Goddess of the Antilles" discute en torno a la temática del agua, pero los primeros cuatro de los trece poemas abordan directamente a los huracanes. Una vez más, el huracán es representado en el contexto de las aguas (no los vientos). Los huracanes serían obras de los dioses, convirtiendo los días que debían ser para la pesca en "Whirling Dervish Days", intervenidos con "sun passages", donde mar y tierra quedan revueltos ${ }^{29}$. El día se medía en horas sin tiempo, "They were sea-soaked hours without time". ${ }^{30}$ Es evidente la destructividad del meteoro, la entrada del mar que tira abajo los techos, los árboles y revuelve el mar, pero el poema de Manoo-Rahming comunica la experiencia del impacto desde una marcación cultural e íntima que recurre a la pérdida de la pesca cotidiana, evoca la comida, y convierte la oscuridad profunda en una fuente de memorias y ensoñaciones: es el huracán que incita la memoria. Este es el proceso narrado en el poema que abre la sección, "No Grouper Days". El segundo de la serie, "Hurucan Floyd" 31 nos presenta al ciclón como si fuese "alguien". No olvidemos la importancia de los nombres, que familiarizan estos demonios, haciéndolos tangibles y partícipes en la comunidad. Este Floyd "is a shape-shifter", un ser movedizo y trans, a veces mujer (Irene, Lily), a veces hombre (Floyd o Denis) ${ }^{32}$.

Cuando finalmente se aleja, lleva consigo "the photos Hurucan wrap up/in she kerchief/and stick in her bosom"33. Arranca y vuela con los documentos, pero los guarda: cuando vuelva, volveremos a recordar, pues el huracán, resguarda todo lo que lleva. Mientras, todo el poema-huracán se edifica como una fotografía de la comunidad, narrando quienes habitan allí, en qué trabajan y cómo piensan. No es casualidad

29 Ver, "No Grouper Days"; "Hurucan Floyd"; "Healing After Hurricanes Frances and Ivan"; In the Time of Hurricane Jeanne", en Immortelle and Bhandaaraa Poems, Lelawattee Manoo-Rahming (Hong Kong: Proverse Hong Kong, 2011)

30 Lelawattee Manoo-Rahming, Immortelle and Bhandaaraa Poems, 67, verso 13.

16431 Huracán Floyd, septiembre 1999. Estuvo 12 horas encima de Las Bahamas antes de continuar su trayectoria hacia la costa este de Estados Unidos.

32 Lelawattee Manoo-Rahming, Immortelle and Bhandaaraa Poems, 68, versos 1-7.

33 Lelawattee Manoo-Rahming, Immortelle and Bhandaaraa Poems, 70, versos 51-54. 
que el epígrafe del poema sea un verso del poema de Derek Walcott "Hurucan" que pertenece a una colección de poemas sobre viajes y viajeros, cartografías de islas y mapeo de mundos $^{34}$. De esta manera, la metáfora expande los significados desde la intertextualidad y refuerza los patrones de repetividad, que permite transformar el archivo del huracán en un repertorio ${ }^{35}$. Y es dentro de este repertorio, en donde las acciones de un pensamiento milenario son correspondidos desde el conocimiento tradicional. En "Healing After Hurricanes Frances and Ivan"36, por ejemplo, las hierbas medicinales curan los estragos del huracán. Es un ser vivo, parte de la cotidianidad y la experiencia comunitaria: no es un fenómeno ajeno. El poema (soneto) es un canto ritual que cura, refuerza y sigue adelante: "To mend/build our lands and heaths/To make us bloom out of season/Like poinciana blossoming/In September after greening"37.

En estos ejemplos, los huracanes se articulan simultáneamente con un mundo natural que avanza mano a mano con los dioses y también con la comunidad. Cada texto construye una representación del huracán, pero la iteración de tropos y de motivos en cada relato y poema construye, a su vez, una rizoma de experiencias cotidianas que reconoce y da cuenta de "the link between creativity, imagination and the effects of particular world views and experiences of the world ${ }^{38}$. En los textos analizados aquí, el huracán es un factor móvil. Su función narrativa como conector, vinculando experiencia y relato, nos otorga una primera serie de tropos que traslapan las cualidades íntimas de lo humano con lo espiritual y lo natural, privilegiando su forma y naturaleza trans, como shape-shifter.

34 Walcott, Derek, "Hurucan" en The Fortunate Traveller. Farrar, Straus, Giraux, New York, 1981.

35 Diana Taylor, El archivo y el repertorio. La memoria cultural performática en las Américas (Santiago de Chile: Ediciones Universidad Alberto Hurtado. Kindle Edition 2015)

36 Los huracanes Frances e Ivan se formaron durante la temporada 2004, en categoría 4 y 5 respectivamente. El huracán Ivan fue bautizado "el Terrible". Los dos nombres fueron retirados de los listados oficiales, por los cuantiosos daños causados.

37 Lelawattee Manoo-Rahming, Immortelle and Bhandaaraa Poems, 71, versos 11-14.

38 Stephanie Posthumus, French 'Ecocritique': Reading Contemporary French Theory and Fiction Ecologically (Toronto: University of Toronto Press, 2017), 6. 


\section{Desde la costa hacia el interior: Cartografías textuales de la Península}

\section{They were sea-soaked hours without time \\ Lelawattee Manoo-Rahming}

Siguiendo el movimiento de los vientos de oriente a poniente (en contra de las manecillas del reloj, y cómo encontramos en la representación taíno del huracán), el corpus analizado registra textos del área costeña de Chetumal, Cancún, Celestún y Campeche; y en el interior del Estado, concluyendo el movimiento de los vientos huracanados al volverse a girar en espiral, de occidente a sur-oriente, de Halachó, Sucilá, Izamal y Oxkutzcab. Algunos de los textos de este corpus han sido registrados y analizados en dos trabajos previos ${ }^{39}$ donde se planteó como posible eje de trabajo el estudio de los huracanes en la literatura en Yucatán y en Belice, como parte de lo que el escritor beliceño Yasser Musa, llama "the hurricane zone". En este trabajo, el enfoque es sobre el corpus de la península de Yucatán (desde costa e interior), lo que ha permitido trazar un mapa de la zona, desde los eco-relatos.

\section{Mapa No. 2}

Los relatos de huracanes en puertos y pueblos de la península.

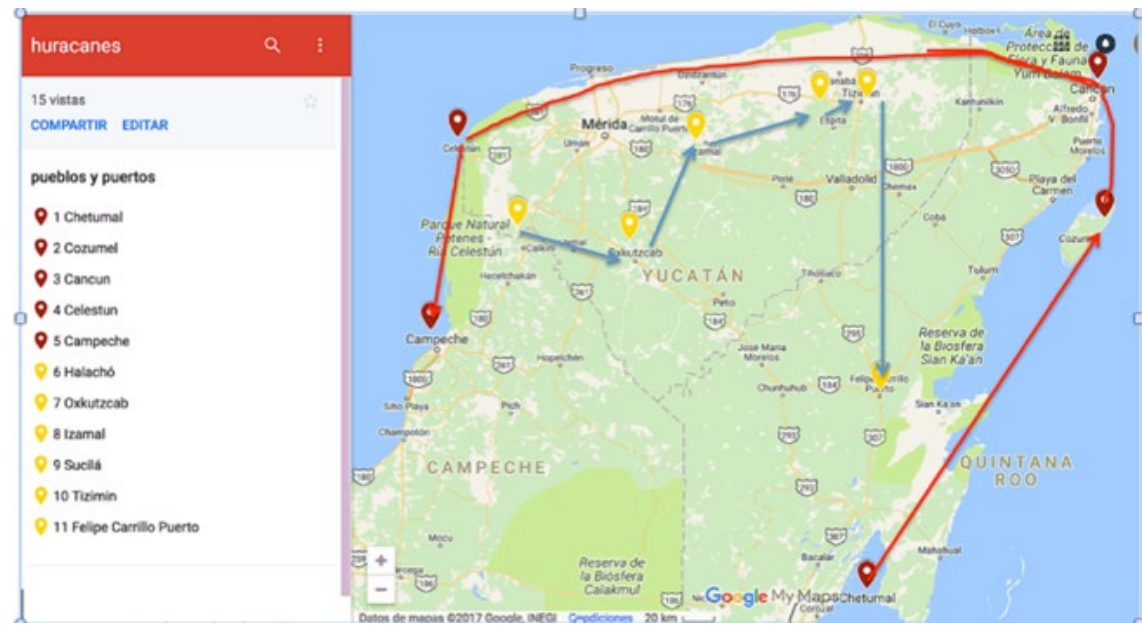

Elaboración propia.

39 Margaret Shrimpton Masson y Daniel Can Caballero, "Memoria e identidades en Celestún, Yucatán. Relatos de pesca, sal y ecoturismo", en Múltiples voces, diversos diálogos, eds. Silvia Cristina Leirana, y Celia Rosado Avilés (Mérida: Universidad Autónoma de Yucatán, 2017); Shrimpton "Cartografías de la memoria". 
Los puntos marcados a color en el mapa son los puertos -los puntos de impacto de los huracanes Janet (1955) en Chetumal, Wilma (2005) y Gilberto (1988) en Cozumel y Cancún, y Gilberto, Ópalo (1995) y Roxana (1995) en Celestún y Campeche. Los puntos en amarrillo son los pueblos al interior de la península, marcando el impacto de Isidoro (2002) y Gilberto (1988). En el caso de los relatos recopilados del interior del estado, no todos narran la experiencia del impacto directo del huracán, pero de alguna manera repiten las repercusiones y resonancias de los meteoros, lo que se podría identificar como una cultura de huracanes. En este caso, los relatos de huracanes ofrecen una manera de realizar una cartografía de la zona, mapeando, los tiempos, espacios y experiencias comunitarias en lo que Adam Barrows llamaría una mediación entre lo global y lo local: "literature is ideally suited to spatially conceptualize temporal experience, but that in so doing, narrative fiction can intervene meaningfully in the problems of mediating between locality and globality, place-based and planetary existence, and spatial conception and temporal transformation" ${ }^{40}$. Común a todos los relatos, es lo referente al agua -el factor mucho más dañino que el viento; el ruido y/o súbitamente, el silencio; la personificación del huracán y la identificación mítica, como fuerza viva; la duplicidad del huracán como factor del bien y del mal; y el factor tiempo.

\subsection{El PRIMER giRo De los VIENTOS: Chetumal}

En la zona de Chetumal los huracanes de principios del siglo XX fueron nombrados por los pobladores mismos. Si bien la lista internacional de nombres inicia en 1955, los registros locales muestran que al menos durante el siglo XX, desde 1900, hay registros de los huracanes con nombres otorgados desde la comunidad, mayormente con nombres de santos. Estos fenómenos, destructivos y temidos, pero "familiares" y conocidos, todos recibían nombres. El Enciclopedia de Quintana Roo tiene una sección sobre huracanes, donde se menciona el arribo e impacto en tierra de cinco huracanes entre 1903 y 1955 a los cuales cuatro recibieron nombres por los pobladores afectados (San Hipólito, San

40 Adam Barrows, Time, Literature, and Cartography After the Spatial Turn: The Chronometric Imaginary (New York: Palgrave, MacMillan, 2016), 24. 
Luis Rey, Santa Mónica y San Maximino). Repetidamente encontramos referencias al huracán como shape-shifter, (como en el poema de Manoo-Rahming, citado arriba) o en el caso de los relatos en torno a Janet cuando entró a Chetumal "[...] vestido de mujer, arrogante, implacable, violento" ${ }^{41}$. En los recuerdos recopilados en Álbum de la familia, la importancia de los nombres queda registrada como acta de memoria, como anales de la historia familiar y comunitaria: el huracán, es nombrado y reconocido: "Janet, Hattie, Gilberto, Wilma, hasta el "sin nombre del '31': todos tenemos un huracán en la familia”. Es una manera de marcar tiempos: con cada nuevo huracán se recuerdan los anteriores.

Parece que fue ayer... Álbum de familia es un volumen en dos tomos, que recupera la historia de Chetumal desde la memoria de varias familias entrevistadas. Igual que en el Enciclopedia de Quintana Roo, el Álbum de familia dedica una sección a los huracanes: una sección del territorio, y la memoria que produce, se entiende desde los ciclones. En Álbum, la sección se titula "Huracán Janet: el huracán que cambió la historia". Guarda semejanza con la reconstrucción de Merle Collins sobre la misma Janet, descrita arriba, el huracán como parte-aguas, un antes y después en la memoria. Es también el caso de otros procesos huracanados, donde Janet "Vino a concluir lo que otro huracán, también vestido de mujer, el Hilda, iniciara once días antes en Felipe Carrillo Puerto, Vigía Chico, la parte centro de la entidad"42. Es también el caso de Frances, Iván y Jeanne, en los poemas de Lelawattee Manoo-Rahming, y de Ópalo y Roxana, en los relatos de Fausta Gantús. El tiempo en la comunidad se cuenta y se mide por el paso y estancia de los ciclones.

Son veintidós personas, habitantes de Chetumal, cuyos relatos se recopilan en el texto. Con estas narraciones en torno al huracán Janet (1955) se observan elementos comunes: la gran mayoría graban el paso del huracán hora por hora. Se personalizan, y el huracán se inscribe en la memoria de cada persona, a través de cada uno de sus movimientos: "A las 10 y media regresamos todos a nuestros refugios, no podíamos

41 María Cecilia Lavalle Torres (ed.) Parece que fue ayer... Álbum de familia (México: 2004), 337.

42 Lavalle, Parece que fue ayer, 337. 
hacer nada más. A las 11 de la noche una madera se estrelló contra la casa, la puerta se rompió y vino una explosión, la casa voló y 200 personas nos quedamos a merced del ciclón"43. De cara a Janet, Antonio Handall Marzuca exclamó: “¡El mar Caribe se nos vino encima!”44. Los comentarios recopilados sobre el impacto del huracán Janet (1955) en el área de Chetumal visibilizan -a nivel de la población- el sentir de pertenecer a una zona del huracán. Permiten dibujar un mapa que traza espacios y límites y plasma experiencias comunes: "En Xcalak, a través de la radio que instalé en mi casa, oí las noticias de Belice, de Miami y del Colegio Belén de La Habana. Por esas fechas estábamos atentos a las noticias, porque era época de ciclones y estábamos acostumbrados a los preparativos. Acababa de pasar el ciclón Hilda, que arrasó Vigía Chico y Carrillo Puerto, y del cual, a nosotros, en Xcalak, solo nos tocó 'la colita"'45.

La trayectoria del huracán traza un macro-espacio en el giro espiral a través del Caribe y otro micro-mapeo hacia adentro: los relatos marcan con una referencialidad precisa el impacto del huracán a lo largo de calles específicas, haciendo hincapié en casas y tiendas en el camino. El mini-texto de Jaime Tirado Beltrán, recuerda: "Vivía frente al mar, en una casa del señor Calín Asencio, junto a la casa de Pepe Padrón [Boulevard Bahía con 5 de Mayo]. Ante la inminente entrada del ciclón a Chetumal, Neguib Farah me dijo que no me quedara en mi casa, que era muy peligroso, y me invitó a Casa Lucy. Neguib me salvó la vida”. ${ }^{46}$ Y continúa para ubicar el Café La Nevada, y el Palacio de Gobierno. Más adelante los diversos narradores mencionan el Hospital Morelos, el Hotel Los Cocos y la Escuela Belisario Domínguez, cada uno improvisado como refugio. Se referencia la tienda Casa Amar de la familia de don Nahim Amar, "la casa que albergaba Caobas Mexicanas", la avenida Othón P. Blanco, y la avenida "16 de Septiembre entre Ébano [hoy Álvaro Obregón] y Zaragoza" y la Casa Villanueva ${ }^{47}$, y tal vez la más famosa de todas, "la casa voladora", de la familia Bellos Sosa: "La

43 Herrera en Parece que fue ayer, 344.

44 Handall en Parece que fue ayer, 344

45 Handall en Parece que fue ayer, 341.

46 Tirado en Parece que fue ayer, 338.

47 Tirado en Parece que fue ayer, 339-343 
historia dice que fueron más de cuatrocientos metros los que recorrió la casa" ${ }^{48}$, con toda la familia adentro. Con su paso sobre Chetumal, el huracán dibuja con pinceladas, la organización familiar, económica y espacial del área.

Al paso del huracán, inició la evacuación de niños y mujeres, y la reconstrucción. Explica Martha Silva lo que significó la ruptura y desintegración de las familias:

"Yo era muy pequeña, pero recuerdo con claridad a mi madre y a muchas como ella, llegando con sus hijos a galerones inmensos en la ciudad de México, repletos de damnificados de Quintana Roo y de Tamaulipas; y que ahí, solas, sin recursos económicos y en una ciudad extraña, debían sacarnos adelante. No solo era el sufrimiento de lo perdido, sino también de la forzosa desintegración familiar, pues los hombres se habían quedado en Chetumal para ayudar en la reconstrucción"49.

Las familias que se quedaron hacen hincapié en el arraigo, y pertenencia al lugar. Fina Muza reafirma "Volvimos a empezar todos. Yo no me fui, ni me iré, éste es mi lugar y yo lo quiero" ${ }^{50}$. E Iván Villanueva Aguilar repite "Quienes nos quedamos después de Janet llevamos al terruño dentro del alma" 51 . Trazamos las huellas de un imaginario fantástico, la construcción de una identidad arraigada en el espacio, en el lugar -un territorio borrado y reconstruido por los ciclones, que inscribe su historia en cada marca de agua y cada relato recopilado.

\subsection{El SEgundo GIRO DE LOS VIENTOS: CANCÚN}

Maura Barea nació en Cancún en 1981. Es autoafirmado cancunense y junto con otros jóvenes escritores nacidos en Quintana Roo y Cancún impulsa el reconocimiento de la identidad cancunense a través del arte creativo -poesía, cuento, blogs. Actualmente, radica en Cádiz, España. 
El cuento "Tierra Incógnita" se publicó en $2015^{52}$. Narra la pre-historia de Cancún, cuando dos ingenieros de la Ciudad de México son enviados a reconocer el terreno en una especie de viaje de descubrimiento. Cancún como tal, no existe aún y el cuento juega con la idea de la ciudad futura, y el paraíso natural, aquel pre-Caribe, plasmado en el Diario de Colón. El ingeniero-narrador, asume el rol de mensajero, mensajero del mal agüero, dándose cuenta de lo que significará para el futuro de la zona: "Mensajeros de que el país y el progreso caerían sobre ellos muy pronto y sin misericordia, como la tromba que había surgido de la nada, y mi castigo sería presenciarlo [...] la premonición de lo inevitable" ${ }^{53}$.

Este cuento se publica diez años después del primer texto largo de Barea sobre el huracán Gilberto, Corazón de cielo. En una presentación del autor en la Universidad Autónoma de Yucatán en 2016 me había proporcionado una serie de textos cortos que leí entonces como minificciones, y para las cuales "Terra Incógnita" resultara entonces como preludio y premonición, como una precuela. No obstante, en conversación reciente con el autor en septiembre de 2017 me aclaró que las minificciones corresponden a secciones de la novela Corazón de cielo. No obstante, cada uno parece desarrollarse en (o a partir del) contexto plasmado en "Terra Incógnita", la historia que llega después de la pre-historia: una serie de narraciones (postcoloniales) que vuelven a dar los pasos del neo-descubrimiento y re-colonización de un Caribe del siglo XX. En términos de la elaboración creativa de los trabajos, estos no fueron concebidos por el autor como precuela/secuela, pero los fragmentos tampoco son exactamente iguales a las secciones en la novela original, y permiten establecer una lectura de los huracanes a partir de un texto fragmentado.

El primer fragmento corresponde al segundo capítulo de la novela "El monstruo se acerca. 12 y 13 de septiembre de 1988" y se remonta a los primeros años de Cancún cuando "Cancún era una ciudad adolescente de dieciocho años [...]" "54. Para 1988 existe un turismo incipiente y ape-

52 Mauro Barea, "Terra Incógnita”, Revista Castálida № 56 (2015).

53 Barea, "Terra Incógnita".

54 Mauro Barea, Corazón del cielo, (Cancún: inédito, 2005), 20. 
nas los inicios de una "industria sin chimeneas" 55 . Los siguientes fragmentos (las minificciones seleccionadas) registran el impacto de Gilberto y de Wilma. El autor aclara que el último fragmento no corresponde a la novela, sino a otro texto, "X años con Wilma" elaborado sobre el huracán Wilma de 2005, y publicado en el blog "De ninguna parte". La "precuela" paradisíaca, "Terra incógnita", y la explicación en el fragmento del capítulo dos de un veloz "relleno" del no-lugar, del espacio (vacío) del paraíso y su conversión en lugar, habitada, y explotada ${ }^{56}$, sirven para la escenificación de la metáfora de neo-descubrimiento, colonización y destrucción que se desarrollará en las posteriores secciones, con los impactos en el área de los huracanes Gilberto (1988) y Wilma (2005).

El segundo minificción también corresponde al segundo capítulo de la novela Corazón del cielo. Relata el crecimiento de la ciudad, a finales de los ochenta, mostrando la edificación justo antes del huracán Gilberto. Es, nuevamente, de augurios y se ubica en una temporalidad a punto de suceder o que aún no ha llegado: "A finales de los ochenta, no era necesario pedir permiso para acceder a cualquier playa dentro de la Zona Hotelera"; "El Party Center no era todavía el Callejón de los Milagros", "Nadie se desgarraba las vestiduras por todos los robos, asesinatos y suicidios" 57 . Tiempos de premonición, tiempos de espera. El factor "tiempo" es un constante en estas narrativas de los huracanes. Hay un tiempo de antes, durante y después, con sus respectivos ritmos.

El tercer fragmento es el segmento número 25 y se sitúa todavía antes del impacto de Gilberto, nombrado el huracán del siglo (XX), que entró a Cozumel el 14 de septiembre de 1988. Las 27 secciones, minificciones de esta parte de la novela, comprenden una de las secciones más largas -corresponde a la espera, una espera que se narra casi minuto

56 El uso de los conceptos de lugar y no-lugar de Marc Augé (1992) aquí, es con cierta ironía, pues en realidad, se presencia el revés de los términos: la destrucción del Caribe con la llegada del turismo convierte el lugar (antes) en no-lugar (después). Ver. Marc Augé, Los no-lugares. Espacios del anonimato (Barcelona: Gedisa, 2000).

57 Barea, Corazón del cielo, 23-24. 
por minuto, y paso a paso. El cuento muestra Cancún bajo un velo de inocencia "jovenzuelo", y aún aquel "paraíso de las palmeras" con el que soñaban los ingenieros de "Terra Incógnita".

Una pausa marca la suspensión y eterna espera característica de los ciclones: se interrumpe la historia pre-ciclón, para retomar después:

"A pocas horas del arribo del monstruo, Cancún se salpicaba de claroscuros: la energía eléctrica comenzaba a falsear en algunas zonas, dejando sumidos en la penumbra ventosa a los asustados e incrédulos cancunenses, que todavía trataban de digerir lo que sucedería el día de mañana, si es que lo había. Cancún se sumía en una temerosa quietud al rozar la medianoche, sin tráfico, sin gente, como una lata vacía de cerveza. [...] Un silencio que presagiaba lo terrible, lo impensable para un paraíso" $" 58$.

Concluye esta parte con la representación de Gilberto, como amenaza, como dios portentoso, y como ser vivo: "De repente creyó que ya soñaba o estaba muerto cuando se vio entre montañas de agua que se alzaban y bajaban como enormes dientes; eran las fauces de Gilberto, que al fin llegaba para llevárselos. Se hundió en el pecho de su padre hasta que por fin cayó en la inconsciencia del sueño, o de un golpe fortísimo. La oscuridad total" 59 .

La novela termina con un epílogo que teje juntos las historias de los huracanes después de Gilberto y concluye en el año de publicación, en 2005, con Wilma. Uno de los hilos conductores en la representación literaria de estos ciclones es su personificación dentro de la comunidad, y frecuentemente es identificado como un dios. En la obra, desde unas páginas antes, se describen las fauces de Gilberto, estableciendo un paralelo con el dios Kukulcán (el serpiente emplumado); y a lo largo de la novela, Barea utiliza una serie de epígrafes cuidadosamente escogidos

59 Barea, Corazón del cielo, 121. 
del Popul Vuh, con los que construye el dios Hurakan, como Corazón del Cielo. Al concluir la novela, el huracán es caracterizado como un ser con un solo ojo, "El remolino sonreía con su único ojo". Es un ser conocedor, que también predica: "Pero claro que sonreía, le sonreía a las ratas y a la oscuridad de los días venideros. Y a un lado, cinco letras en rojo sangre distinguían su nombre, las exponía con orgullo siniestro, como si ella misma supiera que formaría parte de la Historia de la Tierra y de sus pueblos" ${ }^{\prime 0}$. Barea consigue narra ambos huracanes juntos, yuxtapuestos, construyendo Wilma a través del recuerdo de Gilberto, una especie de Gilberto al poder de dos: se registra el impacto del huracán y la experiencia vivida en el sujeto, narrador. Se evidencian los procesos familiares: nombrar el huracán, convertirlo en ser, sentirlo, ser penetrado por él, no comprenderlo, reconocerlo como extraño. Sería pertinente también reconocer en este relato, la presentación del huracán como combinación del bien y del mal, sugerida en la sonrisa destructiva citada aquí. En la cosmovisión maya (y otras cosmovisiones no occidentales) el agua es, por supuesto, símbolo de creación, destrucción y recreación $^{61}$.

\subsection{El tercer GiRo de los vientos: CAMPeche}

En septiembre-octubre de 1995, el puerto y estado de Campeche vivió una experiencia insólita. La historia de los huracanes Opal y Roxana es narrada por Fausta Gantús en el pequeño cuaderno Testimonio de las aguas. Los días de Opal y Roxana. Opal y Roxana sorprendieron al cruzar ambos el territorio peninsular-campechano en un período de 17 días. En el caso de Roxana, su extraño comportamiento se evidenció en un espectacular giro de $180^{\circ}$. El meteoro salió una vez de Campeche, solo para dar una vuelta completa y volver a entrar: "pero ellos mismos no presentían que Roxanne engañaría la sabiduría del hombre vistién-

60 Barea, Corazón del cielo, 197.

61 Agradezco a Charles Pigott la observación sobre la sonrisa del huracán y los ciclos del agua en la cosmovisión maya. 
dose otra vez de huracán para regresar, sorpresivamente a concluir su obra" ${ }^{\prime 2}$.

El Testimonio centra su narración en el tercer capítulo "Días huracanados: Opal y Roxanne", pero los dos breves capítulos anteriores ofrecen el contexto específico para el desarrollo de la narrativa particular que elabora Gantús. El primer capítulo recupera referencias bíblicas y también mayas, en torno a la relación hombre/agua, para argumentar sobre la influencia del agua en el destino de la humanidad. Si bien la relación bíblica es sencilla y maniqueo, el interés en el agua al hablar de huracanes es de suma importancia y guarda conexiones más profundas con el pensamiento maya. Como en el anterior cuento, a lo largo de este testimonio, -con título Testimonio de las aguas - se privilegia el lugar del agua como creador y destructor simultáneamente. Así, en el segundo capítulo, "Retrospectiva", Gantús arma el escenario en dónde actuarán Opal y Roxanne. Remontando a un huracán de 1807, explica: "Cuando en 1807 las aguas alcanzaron alturas tales 'que se podía transitar perfectamente en cayucos y botes hasta la plaza mayor...' (Álvarez: 1991: 245), los habitantes del entonces todavía Distrito de Campeche pensaron que se avecinaba el fin del mundo o que, simplemente, la ciudad entera desaparecía"63. El impacto de este fenómeno desvaneció y dejó en evidencia aquel dualismo de las aguas que "limpiaron las calles y la vida continuó su curso" "64. Usando diversas fuentes entre leyendas y crónicas, Gantús documenta una tormenta en Campeche en 1565. Posteriormente, cita a Francisco Álvarez Suárez quien proporciona datos para el siglo XIX, mencionando huracanes en 1807, 1869, 1887 y 1889. Afirma Gantús que con estos fenómenos "lluvia, mar y ríos se confundieron formando océanos donde las islas eran los hombres que luchaban unidos" ". Existe "memoria grabada en varias fotografías" de la gran inundación de 1936 y en la memoria popular "casi olvidados e irreconocibles, asoman a sus labios los nombres de Flora y Janeth, sin precisar fechas, casi bautizando aquellos otros difíciles días que ya han

62 Fausta Gantús, Testimonio de las aguas. Los días de Opal y Roxana (Campeche: Ediciones La Ola, 1999), 34 .

63 Gantús, Testimonio de las aguas, 19.

64 Gantús, Testimonio de las aguas, 19.

65 Gantús, Testimonio de las aguas, 20. 
quedado demasiado atrás para recuperarlos todos"66. De nuevo, el agua es el elemento de daño, destrucción y reconfiguración del espacio.

En el capítulo III, el texto de Gantús ofrece una crónica de la llegada, la estancia y el paso de los dos huracanes, Opal y Roxanne. La narrativa evidencia una particular manera de marcar el tiempo, hace hincapié en el agua (antes que el viento), se refiere a los huracanes como seres antropomorfos, y se repite como constante la necesidad de contar y de registrar la historia. La crónica abre marcando el revés del ciclo natural, con el día convertido en noche: "La noche llegó para la entidad el 29 de septiembre, con 36 horas de lluvia continua a cuestas" y un extraño amanecer: "Amanece sin sol el sábado" ". En cada fecha de la crónica, el paso del tiempo se marca con el avance caprichoso de los aguas, inundaciones y mares: "Las horas transcurrían al mismo tiempo que los niveles de agua aumentaban [...] Durante todo el domingo, primero de octubre, continuaron las lluvias" "68. Sigue la crónica, apuntando el aumento de las tensiones y las aguas, casi día por día, como amenaza constante: "La preocupación se apoderaba de la población, a la par que las calles inundadas se multiplicaban [...] las calles del centro de la ciudad lentamente cedían, se entregaban al agua que, prácticamente, las devoraba" 69 . Y continúa, "Durante la madrugada, mientras la población dormía, el agua ganaba terreno .... entraba silenciosa y sorpresivamente a las casas del centro, provocando que sus moradores, como si tratase de un ataque pirático, las abandonaran..."70. Finalmente, la crónica también incluye los datos duros: "En solo quince días, almacenamos casi la mitad de la lluvia que llega en un año"71.

Por un momento, la crónica respira y Gantús explica el paso natural de lluvia a sol al alejarse el ciclón. Descubiertos cielo y tierra, se daba la apariencia de retornar a lo normal: "Veíamos el cielo y sentíamos la tierra, como aquel viajero que regresa al lugar que lo vio nacer, después de un largo viaje". Los sentidos y el tiempo aquí construyen un efecto dramático, pues han pasado solo siete días. Lo caprichoso de este meteoro

66 Gantús, Testimonio de las aguas, 23.

67 Gantús, Testimonio de las aguas, 25.

68 Gantús, Testimonio de las aguas, 26-27.

69 Gantús, Testimonio de las aguas, 26.

70 Gantús, Testimonio de las aguas, 26.

71 Gantús, Testimonio de las aguas, 32. 
ocupa el resto del relato. Gantús narra la llegada y viraje de Roxanne como personaje: los vientos y la lluvia "pisotean". Al llegar de nuevo, Roxanne "se arremete" -como Opal, caracterizado antes como pirata. Con Roxanne, desfilan el mar y las olas, transformados en poderosos actantes, caracterizados por una relación con el espacio/tiempo, y una acción sobre y dentro de la comunidad, casi como un ser fantástico: "Otro día demoró el mar. Aquí que no conocemos en la bahía más olas que las de la brisa de la tranquilidad, la marejada echó bocanadas de agua y espuma hasta de 4 metros, olas con pulpos y peces y otros animales marinos entre sus dientes. La marejada se sentó en las calles de la ciudad". ${ }^{72}$ Para Gantús, quien cambia de voz narrativa a lo largo del texto entre primera y tercera singular y tercera plural, el testimonio la consume y a la vez le permite continuar. Deja de ser individual al incorporarse a la voz colectiva. Cierra el capítulo con las voces de todos como testigos múltiples y unidos: "[...] fuimos testigos de lo que la humedad carcomió, de lo que el viento golpeó, de lo que la lluvia perforó y ahogó, de lo que el mar reclamó por unos días, de lo que el agua nos dejó"73.

En el último capítulo, "Recuento final”, Gantús, vuelve al testimonio en primera persona, para afirmar lo aprendido. Apela a lo mítico, la memoria y lo universal: el Testimonio de las aguas, se inscribe en un ciclo natural, sin ser un reclamo o un lamento, se convierte en un registro de sobrevivencia y continuidad:

"Al final una cosa sé de cierto: No podremos olvidar la lluvia interminable, las aguas míticas cubriéndolo todo, arrastrándolo todo, intentando destruir el testimonio de lo que somos, borrando de un zarpazo la memoria, humedeciendo el pensamiento, los sueños y el deseo, hermanándonos con el Macondo detenido en el tiempo: pero regalándonos la posibilidad de renacer de las cenizas con un solo corazón para todos.... si los tiempos de calma lo permiten" 74 .

La lectura del huracán en este texto, es nuevamente una meta-narrativa que cartografía la zona; no es una crónica de un desastre, sino la crónica

72 Gantús, Testimonio de las aguas, 36.

73 Gantús, Testimonio de las aguas, 39.

74 Gantús, Testimonio de las aguas, 42. 
de un ser temible, y como si fuese parte de la familia o la comunidad arroja un relato, una historia de cada miembro del pueblo, y las anécdotas de estos vientos de agua marcan las fechas históricas del pueblo, una bitácora comunitaria de siglos de memoria. El conjunto de textos analizados en el ciclo de vientos costeros (Chetumal, Cancún, Campeche) evidencia un corpus de relatos que recoge la experiencia cotidiana del huracán en las comunidades. Identifico tropos recurrentes en torno al agua, las dualidades creativa-destructivas del ciclón, la personificación del huracán y/o su deificación en la vida cotidiana del pueblo. Así, los relatos costeros establecen una primera cartografía del huracán en la Península yucateca.

\subsection{VIRAJE SÚbITO: EL GIRO DE LOS VIENTOS, TIERRA ADENTRO}

El 9 de agosto, en la ceremonia del fuego sagrado, los guías espirituales vieron una señal mala en el fuego, uno de ellos

lloraba y se dolía. Tardó mucho en consumirse el fuego, hasta que finalmente nos invitaron a tomar del bumo una vez que se habia conjurado lo negativo... Seguro que Dean no nos tumbará... Patricia Martínez Huchim

Las dinámicas que marcan y articulan los puertos de la costa y de los pueblos al interior de la península permiten dibujar y evidenciar una extraña historia de conexiones históricas y exclusiones conscientes. Varios autores han documentado los procesos de representación territorial durante la Colonia y siglo XIX que han alimentado la idea de un territorio vacío ${ }^{75}$ y que culminan en un imaginario que visualiza un Yucatán dividido en ciudad (Mérida), área maya (rural, al interior) y costa. Tres áreas separadas en un imaginario que elimina eficazmente la cultura maya de las costas y crea una ruptura entre ambos ${ }^{76}$. Una

75 Ver: Gabriel Macías Zapata, El vacío imaginario. Geopolítica de la ocupación territorial en el Caribe oriental mexicano (México: CIESAS, 2004); Ana Elvira Cervera Molina, Ana Elvira, "Fronteras, mapas e islas. La conformación de la frontera peninsular de Yucatán-Belice. Una aproximación dialógica" (Tesis Doctoral, El Colegio de Michoacán, A.C., 2017); Jorge Victoria Ojeda, y Aurelio Sánchez, "Interetnicidad y espacios de convivencia: españoles, indígenas y africanos en la Mérida novohispana, 1542-1620”, Secuencia $\mathrm{N}^{\circ}$ 92, (2015): 7-36.

76 Margaret Shrimpton Masson "Un viaje por los puertos y pueblos de la literatura yucateca" en Yucatán en su literatura: apuntes y perspectivas, eds. Rosely Quijano León, Margaret Shrimpton Masson 
breve mirada al mapa nos muestra una situación distinta, evidente en la toponimia local, y comprendida en las prácticas laborales y culturales de la zona. Es frecuente encontrar pueblos y puertos de la costa e interior vinculados con los mismos nombres: Chicxulub Puerto/Chicxulub Pueblo; Telchac Puerto/Telchac Pueblo; Dzilam de Bravo/Dzilam González; Chuburná Puerto/Chuburná Pueblo. Otros, sin conservar el mismo nombre, conservan prácticas de interacción constante: Celestún y Sisal en la costa, con Hunucmá al interior; San Felipe y Río Lagartos en la costa, con Tizimín al interior, para mencionar algunos. Quezada Domínguez reconoce, por ejemplo, las evidencias arqueológicas, etnográficas y ecológicas que dan cuenta de una "zona simbiótica" para la península de Yucatán, y un sistema económico diverso que dependía de la interacción de la pesca y la agricultura, incluso, las mismas prácticas que observamos hoy día entre los pueblos costeros y los pueblos al interior $^{77}$. Arqueólogos también han trazado la importancia de Isla Cerritos para los mayas de Chichén Itzá, de nuevo evidenciando la zona simbiótica que propone Quezada Domínguez. Y además, la importancia del comercio entre las antiguas ciudades mayas de Dzibilchaltún (tierra adentro, cerca de Mérida) y Xtambó (en la costa), por ejemplo.

Este corpus de canciones, poemas y cuentos en lengua maya registran y representan otra serie de nexos que atraviesa esta península de puertos y de pueblos, siguiendo los giros de los vientos del huracán. Como observamos en el Mapa 1, los relatos mayas del corpus se originan en Sucilá, Izamal, y Oxkutzcab ${ }^{78}$ y se refieren a los huracanes Gilberto (1988) e Isidoro (2002). El epígrafe con el cual abrimos este último giro de los vientos, se refiere al huracán Dean (2007) y ofrece la perspectiva

y Celia Rosado Avilés (Mérida: Universidad Autónoma de Yucatán, 2013); Margaret Shrimpton Masson y Daniel Can Caballero, "Memoria e identidades en Celestún, Yucatán. Relatos de pesca, sal y ecoturismo", en Múltiples voces, diversos diálogos, eds. Silvia Cristina Leirana, y Celia Rosado Avilés (Mérida: Universidad Autónoma de Yucatán, 2017).

77 Ricardo Quezada Domínguez, "Los recursos marinos: una alternativa alimenticia para los mayas prehispánicos”, Perspectivas rurales Nº 6 (1999): 66.

78 El corpus también referencia textos de Halachó y Felipe Carrillo Puerto, pero no se han incluido en esta discusión. "Ko'one'ex áantaj/Vamos a ayudar", canción de Antonio Canul Uicab, es un canto de solidaridad con los pueblos de Quintana Roo, después del impacto de Wilma (2005); "Chan Mozon/ Pequeño remolino" (1994/2002), de Pedro Iuit Chi, se refiere a un remolino de los caminos, y no a un ciclón. 
maya sobre la región a partir de una enunciación desde la zona norte (Tizimin) y mirando hacia el Sur (Chetumal y Belice), donde más impactó aquel huracán.

\section{María Luisa Góngora (Oxkutzcab) Chan Moson ${ }^{79}$}

"Chan Moson", relato escrito originalmente en lengua maya por la escritora María Luisa Góngora (Oxkutzkab, Yucatán), abre con lo siguiente: "En una caverna vivía desde hace mucho tiempo una familia de remolinos... Los cazadores [...] escuchaban temerosos el ruido del viento dentro de la caverna y por tal motivo nunca regresaban alli" 80 . El cuento se ubica en una tradición animista propia de la cultura maya. Los huracanes viven en la comunidad donde nacen, crecen, y mueren. A lo largo del cuento se muestran patrones de comportamiento de los elementos naturales, patrones reconocidos y respetados por los cazadores y otros habitantes. Los remolinos, al salirse de la cueva buscan un hogar al que deben regresar; se alimentan de agua de mar e interactúan (peligrosamente) con su entorno. Los habitantes del lugar observan la trayectoria y resientan los estragos: reconocen que el remolino necesita encontrar de nuevo su hogar (su cueva) para calmarse, y así entre rezos y comidas le enseñan el camino.

El relato de María Luisa Góngora revela los pasos del ciclón y visibiliza las prácticas de la comunidad. El cuento nombra el impacto devastador de Hilda (1955), personificada en el cuento como Señora Remolino, y Gilberto (1988) personificado como Chan Moson, o Pequeño Remolino. Sin embargo, el relato no se detiene solamente en la fuerza destructiva del meteoro, sino por medio de la personificación narra su lugar de origen, su comportamiento y el ritmo de su movimiento. La

79 Durante una entrevista con Miguel May May (septiembre 2017), me proporcionó también la canción “Chan Mozon/pequeño remolino" (1994/2002) de Pedro Iuit Chi oriundo de Noj Kaj Santa Cruz/ Felipe Carrillo Puerto. Aunque conserva el mismo nombre que el cuento de María Luisa Góngora, el pequeño remolino en esta canción no se refiere a un huracán sino a una práctica entre los mayas, para proteger a los niños que caminan por las veredas: se dirige a un niño, advirtiéndolo no jugar en medio del camino, pues en el medio "anda el pequeño remolino".

80 María Luisa Góngora, “Chan Moson”, en Chan Moson. Pequeño remolino (México: Instituto Nacional Indigenista, 1998), 49. 
ubicación de su morada en la cueva es otro indicador que sugiere la dualidad del ciclón, pues las cuevas en la cosmovisión maya manifiestan propiedades de sanación y de enfermedad, y son lugares de protección y de peligro: en este sentido, los remolinos del relato manifiestan los ciclos vida-muerte. En el cuento Góngora muestra los trazos cíclicos de la ruta del ciclón: en busca siempre del agua caliente, se dirige al mar. El Señor Remolino llevó un camino directo, tirando árboles en el monte, y al llegar al mar: "quiso regresar a su casa y sintió que moría hasta convertirse en una pequeña brisa que se perdió en la inmensidad del mar" ${ }^{\prime 2}$. La Señora Remolino marca un trazo de espirales, las dobles esferas que reconocemos en la iconografía maya y taíno para representar al huracán. Su trazo no es lineal por equivocarse y perderse en el camino después de "bailar sobre el océano", lo que aumenta sus fuerzas, mismas que la alejan del punto de regreso: "Cuando se dio cuenta, la inmensidad del océano la alegró tanto que comenzó a bailar sobre el agua y así comenzó a dar vueltas. Así, se alejó bastante de su hogar hasta que se dio cuenta que estaba perdida. [...] Por encontrar su hogar, mucha gente murió, y por su tamaño no podía encontrar a su Pequeño Remolino. Así siguió un tiempo, hasta que desfalleció" 82 . Pigott observa que la muerte de la Señora Remolino sobre el océano evoca la relación vida-muerte/ciclos naturales, al establecer la continuidad entre la cueva o cenote y el mar, donde la boca del cenote es el lugar del surgimiento y muerte del alma ${ }^{83}$.

El relato concluye con la "salida" del tercer remolino, el "Pequeño". Al convertirse en Gilberto, el huracán del siglo xx, el nombre Chan Moson, el remolino pequeñito, se vuelve apodo irónico. En este último ejemplo, es necesaria la intervención de la comunidad para "regresar" el huracán a su caverna: "Los hombres del Mayab fueron a ver al sacerdote maya... Dijo que con rezos y dándole comida regresaría. Y así fue. Al sentir el aroma de la comida regresó. El Señor del Viento recobró el aire que se había escapado. El Señor de la Lluvia le arrebató el calabazo

81 Góngora, "Chan Moson”, 50.

82 Góngora, “Chan Moson”, 50-51.

83 Pigott, Charles, comentario personal, (2019), con referencia a la obra de Joel W. Palka, Maya Pilgrimage to Ritual Landscapes. Insights from Archaeology, History, and Ethnography (Alberquerque: University of New Mexico Press, 2014). 
a Pequeño remolino y así pasó la lluvia. Cuando Pequeño Remolino escuchó su nombre invocado, regresó a la caverna donde vivía [...]"84. Se recupera el balance perdido, pero no sin antes padecer los estragos del descontrol. Nuevamente, es evidente la relación simbólica vida-muerte, al evocar las ceremonias de Hanal Pixan (comida de las ánimas), celebrada para honrar a los muertos y ofrecerle su camino de regreso para descansar el alma, y desde luego encontrar un estado ecuánime ${ }^{85}$. Así, este cuento transmite no solamente la sabiduría milenaria adquirida y comunicada generación tras generación desde la observación y registro del entorno natural, en complejos procesos de interacción y aprendizaje; sino también construye una forma de narrar.

\section{Vicente Medrano Gil (Sucilá) Chak ik'aal/Huracán}

Esta composición de Vicente Medrano Gil revela la doble mirada al huracán como elemento natural (desastroso) y también, como comenta el antropólogo Gabriel Angelotti, la perspectiva de un niño en torno al significado social-familiar de un huracán:

"Para este niño maya, el huracán no es algo malo, ni está asociado a un hecho destructivo. Por el contrario, es un fenómeno benéfico que le permite acceder a una situación extraordinaria: vivir un día de plenitud, jugar en su casa, y disfrutar del cuidado paterno. La canción es importante porque deja al descubierto los sentimientos y la intimidad de un niño en torno a su situación familiar. Una realidad que es común para muchos niños en Yucatán. Además, es relevante porque devela la diversidad de opiniones, y la existencia de múltiples visiones sobre un hecho natural, respecto del cual existe consenso científico sobre su origen y alcance destructivo" $" 86$.

85 Para más información, ver Roberto González Martínez, "Las entidades anímicas en el pensamiento maya" Estudios de la Cultura Maya 30 (2007): 153-174

86 Gabriel Angelotti Pasteur, "Percepción, miedo y riesgo, ante los huracanes y otros fenómenos naturales en Yucatán”, Temas Antropológicos Vol. 36, № 2 (2014): 62. 
Evidente desde las voces mayas del título ${ }^{87}$ (iik, aire, viento, ánima, aliento; y cháak, lluvia), la canción introduce elementos pertinentes a una cosmovisión maya en torno a la relación hombre/naturaleza (viento de agua - augurio del mal), y en específico con respecto la dualidad que opera al centro de esta cosmovisión. Más de ser un sistema de binarios opuestos (bueno/malo), en el pensamiento maya los binarios son complementos, formando un complejo sistema de asociaciones verbales y de significados donde tanto los difrasismos sinónimos y antitéticos adquieren sentidos de continuidad e incluso metafóricos ${ }^{88}$.

La canción narra - en voz del niño, y de un narrador - la experiencia de un niño con su padre durante un día y una noche cuando impactó el huracán Isidoro en Yucatán ${ }^{89}$. Se registran algunas diferencias entre las dos versiones que se conocen de la canción. La que para este trabajo se maneja como la versión original, se escribió en lengua maya. La traducción al español que utilizo fue realizada por el antropólogo Miguel May May (Junio 2017). La segunda versión que se conoce se encuentra en el documental Lo que cantan los pueblos de Yucatán ${ }^{90}$. Se canta la canción en lengua maya, y en el sitio del documental en YouTube, se incluye la letra escrita en español.

87 Agradezco a Charles Pigott, esta señalización (comentario personal, 2019)

88 Explica Michela Craveri al respecto, "La teoría de los “opuestos binarios", aun con esta distinción cuantitativa, se revela como instrumento útil par comprender la función del recurso, ya que aclara los sistemas cognitivos de las sociedades ágrafas. Los difrasismos, en efecto, son expresiones verbales de los vínculos percibidos entre manifestaciones naturales. En las culturas orales no existen palabras, conceptos y referentes aislados de su contexto vial, puesto que cada elemento adquiere significado por medio de la relación con los otros aspectos implicados en su ambiente natural (Ong, op.cit.: 4651). Así, las plantas adquieren una función específica por la relación con los animales, el Sol con la Luna, el cielo con la Tierra. Esta continuidad vital entre paisaje, dioses, y hombres se refleja en los textos poéticos a través de las asociaciones léxicas de los difrasismos, qe sugieren los vínculos simbólicos y metafóricos que la sociedad observa en el mundo natural" Michela Elisa Craveri Slaviero, "Las palabras que contaron los antepasados: los recursos retóricos del Popul Vuh", Estudios de Cultura Maya Vol. XXVI (2005): 97.

89 Huracán Isidoro, tocó tierra en la costa norte de Yucatán el 22 de septiembre de 2002. Durante 35 horas quedó casi estacionario sobre los estados de Yucatán y Campeche (14 horas como huracán, y 21 como tormenta tropical). http://smn1.conagua.gob.mx/ciclones/tempo2002/atlantico/isidore/ isidore.html

90 La canción "Junp'éel Chaampal /Un Niño" se reproduce en el video cantado por el autor, Vicente Medrano Gil, y forma parte del documental Lo que cantan los pueblos de Yucatán (proyecto auspiciado por el Pacmyc, Estado de Yucatán, 2006). Documental realizado por Felipe García y producido por Juanita Barrera, 2007. Disponible en https://www.youtube.com/watch?v=5ehVSl_vnrQ 
Los primeros versos cantados desafían las percepciones sobre huracanes en la localidad. Aquí, después de apelar a lo que piensa "mucha gente", que los huracanes son malos, el niño comenta al narrador que "A mí me gustan los huracanes". La narración que sigue es lo que canta el niño para explicar por qué. El niño sintetiza primero, y afirma que, por el huracán, su padre no va a trabajar. Antes del huracán nunca lo veía, pues cuando despertaba ya se había ido a trabajar, y al regresar su padre, el niño ya se había dormido. Vinculado al tema del trabajo del padre y la presencia/ausencia en la casa, es, por supuesto, el tema económico y la vulnerabilidad económica de la comunidad. El niño, como vocero, dice que no necesita el dinero, solo quiere convivir con su padre. En este momento, la diferencia de perspectiva entre padre e hijo muestra una tensión entre lo bueno/malo del huracán. El niño pasa a detallar las etapas en el avance del meteoro, desde su perspectiva. Primero se va la corriente, y suena fuerte el viento. No menciona lluvia, ni daños. Pero la vOz del padre se escucha, consolando el niño para que no tenga miedo. El niño, sin embargo, fija en los besos y abrazos del padre, la acción de ir a jugar y luego a cenar juntos. La cercanía de ambos es notable. Las repeticiones marcan la intimidad (me besó/me abrazó; me besó/ me abrazó; me abrazó), y marca una ruptura en la cotidianidad, que se extiende en los siguientes versos. El niño se sorprende cuando se van a dormir, que su padre le abraza y le deja dormir con él. Exclama, "no dijo niño, ve por allá”. Al despertar, el niño ya no encuentra a su padre por que el papá, igual que el huracán, ya había partido.

La equivalencia entre padre y huracán se vuelve interesante e introduce a nivel simbólico la presencia del huracán como un ser vivo y respetado. Las pérdidas que narran el niño, tampoco giran en torno a los daños por vientos fuertes y aguas, inundaciones. La pérdida es de su padre. No obstante, la canción cierra como un himno o rezo de gracias donde de nuevo el huracán es referido como un ser respetado, a quien se le rinde gracias, y esto es repetido cuatro veces. El niño le agradece al huracán por el tiempo compartido con su padre. La realización del sueño crea tensiones, pues provoca la lectura de la canción como deseo, imaginación, sueño, fantasía; los espacios de convivencia que se encuentran en el deseo (en su canto) no son habituales (como explica al principio de la canción). El verso que marca este punto de tensión es "no dijo niño, 
ve por allá", pues indica la sorpresa del niño al no ser excluido de "cosas de adultos". En el pensamiento maya cotidiano el niño no participa hasta ser "completo", es decir, responsable y capaz. Este verso muestra un punto de ruptura, que refuerza el canto del huracán, como sueño, deseo y consuelo.

Las dos versiones de la canción utilizan títulos distintos. En la versión en YouTube el título es "Un niño", mientras en el poema simple es "Huracán". Esta diferencia modifica el sujeto y actante principal de la narración -y, en el caso de "Un niño", da sentido a la interpretación sociológica en torno a los lazos familiares, laborales y de vulnerabilidad a los que se refiere Angelotti. En la versión "Huracán” es importante considerar diferentes aspectos, pues, al volverse el huracán el enfoque central de la canción, se identifica el sistema de difrasismos sinónimos y antitéticos que caracteriza el pensamiento y permite desarrollar la carga simbólica y metafórica de la narración. En primer lugar, el narrador abre la canción afirmando que mucha gente dice que el huracán es malo: "Muchas personas dicen así: El huracán es algo muy malo" (vv. 1-2), y continúa, "No seas malo, ayuda a tu prójimo" (v.6), para luego expresar la visión del niño, "A mí me gusta el huracán” (v. 8). En términos de sentido, se vincula el huracán con un sentido comunitario de "maldad", pero seguido por dos ejemplos contiguos de "bondad", pues el huracán abre la oportunidad para ayudar "al prójimo” (v. 6), y en el pensamiento del niño, para convivir con su padre. Por otra parte, el rol actancial del huracán se evidencia en los versos que se repiten a lo largo de la canción: "Huracán anaranjado mi papá no fue a trabajar//Huracán anaranjado mi papá no fue a trabajar"; "Por el huracán, mi padre no fue a trabajar//Por el huracán, mi padre conmigo se quedó"; "Gracias huracán, por ti//Mi sueño se ha cumplido". Este último par de versos se repite 4 veces. Es el huracán el suceso que impacta, transforma y mapea la experiencia del pueblo.

\section{Víctor Manuel Aarón Sánchez (Izamal) Isidoro II}

Esta canción se escribió el día que pasó el huracán Isidoro (22 septiembre 2002) por el territorio. Ganó segundo lugar en el Primer Concurso de Canción en Lengua Maya (convocada por INDEMAYA en 2002). 
El cantautor cuenta "El día del huracán estaba en mi hamaca y me puse a escribir algo". El relato sobre la canción evidencia el lugar que juega la lluvia: además de repetir como verso "lluvia, lluvia, lluvia" incorpora también el sonido onomatopéyico del agua cayendo con fuerza. Lo notable de esta versión del paso, o mejor dicho "la visita" del huracán (se refiere a la larga estancia que hizo Isidoro, en particular sobre la ciudad de Mérida), son los detalles específicos de su impacto. Es un relato personalizado que refiere primero a la llegada del huracán como un ser (malvado) que llega a la casa: "Hay visitas que son bienvenidas, pero hay uno para no recordar. No te pares sigue tu camino, Isidoro maldito huracán" (vv. 1-3). Continúa, narrando detalladamente lo que arrebató -las marcas de compadrazgo al relatar la pérdida de la lechona de la comadre; la gallina de la vecina; y el pajarito del compadre (vv. 4-6). Los siguientes versos corresponden a la situación individual -la casa destruida, la pérdida de techo, luz y agua. Después de enmarcar esta visita no deseada del ser malvado, concluye la canción con la exposición de la vulnerabilidad, el estado sociológico de Yucatán: "Isidoro ya no vuelvas, ya no vuelvas a Yucatán, a unos ricos dejaste pobres, y a los pobres nos fregaste más" (vv. 10-12, repetidas, 13-15). Al personificar el huracán, su fuerza figurativa se evidencia y crece la denuncia: Isidoro se vuelve sinónimo de otros fenómenos destructivos, y de la explotación y la desigualdad en la zona.

\section{Consideraciones Finales}

Los textos presentados y analizados a lo largo de este trabajo permiten evidenciar una "cierta manera" de narrar el espacio Caribe. La lectura del huracán como meta-narrativa proporciona un lenguaje para mirar, sonar y contar nuestras historias, y contribuye un importante espacio lingüístico para la discusión de regiones como el Caribe, y específicamente, los Caribes continentales. La discusión de estos textos, escritos en distintos idiomas, ha sido organizada conscientemente a partir de una propuesta gráfica y sistémica del espacio, imaginado este, a partir del movimiento y del giro de los vientos. El propósito es considerar los textos dentro de un territorio para observar los diálogos, articulaciones 
y desarticulaciones que se presentan. Los textos como conjunto manifiestan elementos narrativos en común: el huracán como personaje con nombre y cierta "pertinencia", un personaje familiar que pierde su extrañeza, pero que mantiene una presencia mítica; el huracán en relación al agua (la lluvia, las inundaciones, y las entradas de mar), donde el agua se convierte en estrategia para narrar el tiempo; el huracán que genera un lenguaje propio a partir del ritmo entre silencio y extremo ruido; el huracán como alegoría de corrupción, desastre y desigualdad.

Siguiendo el tropo del huracán encuentro entre sus movimientos los trazos constantes entre ciudad y costa, entre el área de monte y los espacios de manglares: una cartografía que lejos de representar el "espacio vacío" que buscaba afianzar el discurso colonial, evidencia un territorio comunicado, poblado y articulado. Esta cartografía de los relatos de huracanes desmantela una serie de divisiones construidos sobre el espacio, y afianza - de acuerdo con varios estudios arqueológicos - una zona articulada y diferenciada. La lectura de los huracanes en textos escritos/ relatados en maya y en español abre un diálogo importante en la zona, al invitar a mirar más allá de las fronteras, tanto políticas como naturales. Como evidencia el cuento "Chan Moson" (María Luisa Góngora) existen diálogos necesarios entre mar, monte y pueblo; entre pobladores y jmeen, entre el huracán y la sociedad (entre raíz y rizoma).

De último, quisiera retomar la propuesta conceptual que introduje a esta discusión, que encuentra en el huracán un paradigma que articula lo ontológico y lo epistemológico. Los huracanes proporcionan "a way of seeing", "a way of speaking" y "a way of telling”, un lenguaje propio para narrar el fenómeno en y de la sociedad. Apropiándome de la astucia y de la profunda percepción de Lamming, Brathwaite y Berger planteo que las poéticas del huracán ofrecen una manera de ver, de sonar y de contar: son tres ejes para la construcción de la memoria y la identidad desde la experiencia vivida. Es decir, el artículo evidencia al huracán como texto, o como un mapa natural de la zona, que realiza una cartografía no solamente del mundo representado, sino de la experiencia del mundo vivido. 


\section{BibliografiA}

\section{Fuentes Primarias}

\section{a) Publicaciones periódicas}

Diario de Yucatán (Mérida), 7 de marzo, 2018. http://www.yucatan. com.mx/merida/mucho-calor-y-lluvia-historica

\section{b) Entrevistas}

Entrevista a May May, Miguel, Mérida, 27 de junio de 2017.

\section{c) Libros}

Barea, Mauro. Corazón del cielo. Cancún, Inédito, 2005.

Barea, Mauro. “Terra Incógnita”. Revista Castálida N 56 (2015).

Collins, Merle. "Tout Moun ka Pléwé (Everybody Bawling)". Small Axe Vol. 11 No. 1 (2007): 1-16. DOI: https://doi.org/10.1215/11-1-1

Domínguez, Jair, y Alfredo Maya. Wilma imágenes de una adversidad vencida. Cancún: Editorial Idea, 2007.

Góngora, María Luisa. "Chan Moson”. En Chan Moson. Pequeño remolino. México: Instituto Nacional Indigenista, 1998, 49-52.

Gantús, Fausta. Testimonio de las aguas. Los días de Opal y Roxana. Campeche: Ediciones La Ola, 1999.

Lavalle Torres, María Cecilia. Parece que fue ayer... Álbum de familia. México: 2004 (2 vols).

Manoo-Rahming Lelawattee. Immortelle and Bhandaaraa Poems. Proverse Hong Kong: Hong Kong, 2011.

Medrano Gil, Vicente. “Junp’éel chaampal/Un Niño”, en Lo que cantan los pueblos de Yucatán. Documental de Felipe García y Juanita Barrera. 2007. https://www.youtube.com/watch?v=5ehVS1 vnrQ [último acceso: 25 de noviembre de 2012].

Medrano Gil, Vicente. Canción: Chak ik’aal (Huracán), Traducción Miguel May May, 2017 (inédito).

188 Muir, Diana. "My Mother's Hurricane, and Further Cautions". The North American Review Vol. 283, No. 2 (1998): 4-8. http://www.jstor.org/stable/25126217. (Accessed: 28-09-2017 23:13 UTC) 
Musa,Yasser. "Like a Dance (April 2013)", en The Girl in Black. Ciudad de Belice: Image Factory, 2014. http://www.yassermusa. com/uploads/3/4/7/0/3470758/the girl in black 2014.pdf

Sánchez, Victor Manual Áaron. Isidoro II. $1^{\circ}$ Concurso de la Canción en Lengua Maya. https://www.youtube.com/watch?v=1Axi-BSP8Mc (Manuscrito, proporcionado por Miguel May May).

Simelda, Kristine. "Stormy Weather". WomanSpeak, A Journal of Writing and Art by Caribbean Women Vol. 8 (2016)

\section{Fuentes Secundarias}

Angelotti Pasteur, Gabriel. "Percepción, miedo y riesgo, ante los huracanes y otros fenómenos naturales en Yucatán". Temas Antropológicos, Revista Científica de Investigaciones Regionales Vol. 36, $\mathrm{N}^{\circ} 2$ (2014): 43-72

Barrows, Adam. Time, Literature, and Cartography After the Spatial

Turn: The Chronometric Imaginary. New York: Palgrave, MacMillan, 2016.

Berger, John y Jean Mohr. Another Way of Telling. New York: First Vintage International, 1995 (1st edition, 1982)

Brathwaite, Kamau. "History of the Voice". En Roots, La Habana, Casa de las Américas, 1986.

Buell, Lawrence, Ursula K. Heise y Karen Thornber. "Literature and Environment", Annu. Rev. Environ. Resour No 36 (2011): 417440. DOI: 10.1146/annurev-environ-111109-144855

Cervera Molina, Ana Elvira. "Fronteras, mapas e islas. La conformación de la frontera peninsular de Yucatán-Belice. Una aproximación dialógica". (Tesis Doctoral, El Colegio de Michoacán, A.C., 2017).

Craveri Slaviero, Michela Elisa. "Las palabras que contaron los antepasados: los recursos retóricos del Popul Vuh". Estudios de Cultura Maya Vol. XXVI (2005): 91-116.

Deckard, Sharae. "The Political Ecology of Storms in Caribbean Literature". En The Caribbean: Aesthetics, World-Ecology, Politics, editado por Chris Campbell y Michael Niblett. Liverpool: University of Liverpool Press, 2016, 25-45. [descargado de academia. edu, $11 / 04 / 2017]$ 
Devries, Scott M. A History of Ecology and Environmentalism in Spanish American Literature. Lanham: Bucknell Universtiy Press/ Rowman \& Littlefield, 2013.

Guzmán Noh, Gertrudis y Juan Manuel Rodríguez Esteves. "Elementos de la vulnerabilidad ante huracanes". Política y Cultura $\mathrm{N}^{\circ} 45$ (2016): 183-210. http://www.scielo.org.mx/pdf/polcul/ n45/0188-7742-polcul-45-00183.pdf

Lamming, George. The Pleasures of Exile. London/New York: Allison and Busby, 1984 (1ª edición, 1960).

Macías Richard, Carlos. "El Caribe mexicano. Historia e historiografía contemporánea". Estudios de historia y sociedad Vol. XXVIII, $\mathrm{N}^{\circ} 111$ (2007): 67-115

Macías Zapata, Gabriel. A. El vacío imaginario. Geopolítica de la ocupación territorial en el Caribe oriental mexicano. México: CIESAS, 2004.

Martínez González, Roberto. "Las entidades anímicas en el pensamiento maya" Estudios de la Cultura Maya 30 (2007): 153-174

McAtackney, Laura y Krysta Ryzewski. Contemporary Archaeology and the City: Creativity, Ruination, and Political Action. Oxford: Oxford University Press, 2017.

McWatt, Mark. "The Guyana Landscape and the Language of the Imagination in the Fiction of Wilson Harris". The Arts Journal Vol. $5, \mathrm{~N}^{\circ} 1-2$ (2009): 31-43.

NHC National Hurricane Center. http://www.nhc.noaa.gov/

Oppermann, Serpil. "Ecocriticism's Theoretical Discontents". Mosaic: a journal for the interdisciplinary study of literature Vol. 44, No. 2 (2011): 153-169

Palka, Joel W. Maya Pilgrimage to Ritual Landscapes. Insights from Archaeology, History, and Ethnography. Alberquerque: University of New Mexico Press, 2014.

Posthumus, Stephanie. French 'Ecocritique': Reading Contemporary French Theory and Fiction Ecologically. Toronto: University of Toronto Press, 2017.

190 Preziuso, Marika. "Mapping the Lived-Imagined Caribbean: Postcolonial Geographies in the Literature of the "Diasporic"'. Caribbean, Journal of Intercultural Studies Vol. 31, № 2 (2010): 145-160 
Quezada Domínguez, Ricardo. "Los recursos marinos: una alternativa alimenticia para los mayas prehispánicos". Perspectivas rurales Vol. 6 (1999): 48-68.

Rahim, Jennifer. "From Archaeology to Iconology: Representations of the Tropics in Senior's "Gardening in the Tropics" and in Goodison's "To Us, all Flowers are Roses"'. Journal of West Indian Literature Vol. 8, N² 2 (1999): 68-82 http://www.jstor.org/stable/23019792. (Accessed: 28-09-2017 23:54 UTC)

Schwartz, Stuart B. Sea of Storms. A History of Hurricanes in the Greater Caribbean from Columbus to Katrina. Princeton: Princeton University Press, 2015.

Schwartz, Stuart B. "In the Shadow of Flora and Katrina: Response to Hurricanes Irma and Maria in the Neoliberal Age". Ciclo de Conferencias Caribeñas, Instituto de Estudios Caribeños (IEC) Universidad de Puerto Rico, Río Piedras (UPR), 9 febrero 2018. http://www.uprrp.edu/

Shrimpton Masson, Margaret. "Cartografías de la memoria cultural caribeña. Eco-relatos en la “zona del huracán”. En Narrar el Caribe: visiones históricas de la región, editado por Laura Muñoz Mata. Ciudad de México: Instituto Mora, en prensa, 2019.

Shrimpton Masson, Margaret. "Islas de tierra firme: ¿un modelo para el Caribe continental? El caso de Yucatán”. Memorias. Revista Digital de Historia y Arqueología desde el Caribe Colombiano Año 11, $\mathrm{N}^{\circ} 25$ (2015): 178-208.

Shrimpton Masson, Margaret. "Un viaje por los puertos y pueblos de la literatura yucateca". En Yucatán en su literatura: apuntes y perspectivas, editado por Rosely Quijano Leon, Margaret Shrimpton Masson y Celia Rosado Avilés. Mérida: Universidad Autónoma de Yucatán, 2013.

Shrimpton Masson, Margaret y Daniel Can Caballero. "Memoria e identidades en Celestún, Yucatán. Relatos de pesca, sal y ecoturismo". En Múltiples voces, diversos diálogos, editado por Silvia Cristina Leirana, y Celia Rosado Avilés. Mérida: Universidad Autónoma de Yucatán, 2017, 165-198.

Victoria Ojeda, J y Aurelio Sánchez. "Interetnicidad y espacios de convivencia: españoles, indígenas y africanos en la Mérida novohispana, 1542-1620". Secuencia $N^{\circ} 92$ (2015): 7-36. 
http:/ / www.scielo.org.mx/scielo.php?script=sci_arttext\&pi$\mathrm{d}=$ S018603482015000200001\&lng=es\&tlng=es. (consultado 25 de febrero de 2018)

Xácur Maiza, Juan Ángel. Fascículo Chetumal/Huracán, Enciclopedia de Quintana Roo. México: Gobierno del Estado de Quintana Roo, 2005.

Para citar este artículo: Shrimpton Masson, Margaret. "Mapas textuales de la península de Yucatán en el Caribe Continental: narrativas de huracanes", Historia Caribe Vol. XV No. 37 (Julio-Diciembre 2020): 151-192. DOI: http://dx.doi.org/10.15648/hc.37.2020.7 